\title{
Modelling the Assessment System of An Enterprise's Result to Ensure A Region's Economic Security
}

\author{
Iraida Ye. Isayeva \\ Volgograd State Universuty \\ Institute of Economics and Finance \\ Chair of International and Regional Economics \\ Volgograd, Russia \\ audit@volsu.ru
}

\author{
Alexandra V. Glushchenko \\ Volgograd State Universuty \\ Institute of Economics and Finance \\ Chair of International and Regional Economics \\ Volgograd, Russia \\ audit@volsu.ru
}

\author{
Yekaterina P. Kucherova \\ Volgograd State Universuty \\ Institute of Economics and Finance \\ Chair of International and Regional Economics \\ Volgograd, Russia \\ audit@volsu.ru
}

\begin{abstract}
The elimination of factors which create either direct or indirect possibility of damaging or threatening a region's economic security is one of the most important directions in providing and maintaining a region's economic security and sovereignty. Thus, one of the regional policy's goals is to ensure the economic growth, which depends on developing and strengthening the real sector of economy. Each enterprise is subject to the influence of numerous internal and external factors, most of which should be considered as significant threats. Such situation negatively affects the financial result of an economic entity, the amount of taxes paid to all budget levels and the GRP in general. Investigating the factors and ways of enhancing the financial result of a concrete enterprise largely depends on the general strategic planning and specific indicators planning in particular. Forecasting the financial-economic activity key indicators is primarily implemented by means of the financial analysis standard toolset and algorithms. In this research, the authors have tried to apply the differentiated approach to using standard analytical procedures. The suggested selection matrix of an enterprise's financial results analysis model allows assessing the advantages and disadvantages of each analytical procedure and choosing the most applicable among them according to an enterprise's financial security development and strengthening goals.
\end{abstract}

Keywords - region's economic security, economic security challenges and threats, factors and ways of insreasing the profit, assessing financial results

\section{INTRODUCTION}

The implementation of Russia's economic security strategy implies elaborating and introducing a set of organizational, legal and methodic measures not only on the state level but in the regions as well. A region's stability and economic security significantly depends on the socioeconomic development, economic entities' financial independence, their ability to pay taxes and be competitive.

The research goal is to give theoretical grounds and elaborate a system of assessing an enterprise's financial result in order to enhance the tax base and strengthen the economic security of a specific economic entity and a region in general

The following objectives have been defined to achieve the main goal:

- Determine Volgograd Oblast's economic security's significant challenges and threats, hindering it from the economic growth;

- Define the regional policy's key directions and objectives for ensuring the region's economic growth in accordance with Russia's economic security strategy;

- Assess the enterprises' financial state and their profit level influence on the region's development;

Elaborate alternatives of assessing financial results for their optimal planning and managing.

\section{MAterials AND Methods (MODEL)}

The system approach to processes and phenomena, being under study, is the methodological basis of this research. A wide range of methods are applied in this study, depending on the specificity of a problem, being solved: deduction, induction, comparison, systematization and generalization of theoretical and practical materials, grouping, analyzing and others, which ensure the validity of final conclusions. 
In the contemporary economic literature the term "economic security" is interpreted in various ways. F. Roosevelt was the first to introduce this term. Later, "economic security" began being widely used because of the resources' scantiness. Today we discuss economic security not only on the state level, but on the regional, economic entities' and personal levels as well. The topicality of economic security is rising due to new conditions and factors, which create either direct or indirect possibility of threatening a person's, enterprises, region's and country's interests.

In May, 2017, Russia's Economic Security Strategy until 2030 (hereinafter referred to as Strategy) was ratified by the Decree of the Russian Federation President. This document contains the interpretation of the "economic security" term, which will be applied further in this research. "Economic security is the national economy's state of being protected, while the economic state's sovereignty, economic space unity and conditions are provided for implementing the strategic national interests of the Russian Federation[1]. The implementation of this strategy implies solving similar problems on the regional and entities' levels.

Volgograd Oblast's socio-economic development policy is aimed at solving the tasks in the three strategic spheres: demographic and social policy, economic potential, ecological situation. [2]. Today the most widely discussed and urgent problems in Volgograd Oblast are increasing the number of enterprises, decreasing the region's population outflow, boosting the share of small and medium businesses in the GRP and etc.. In fact, these problems can be regarded as economic security threats, which damage the region's economic interests. Hence, we will investigate the role of specific economic entities in implementing the region's economic security Strategy from the point of view of those threats, which have become urgent long ago.

The key indicator, influencing the region's economic development is the tax collection and amount rate. After having studied the statistical data, we have found out that the economic entities' corporate tax is the key indicator of the whole region's welfare. There are two main views on the term "profit": economic and accounting. In general, both views are similar. They say that profit is the difference between the income and full costs. However, economists and accountants have different points of view on what full costs mean.

From and accountant's point of view, costs are all those expenditures, which have been born and later verified by the primary documentation. In other words, there are five costs elements: material expenditures, labour payment expenditures, social security contributions, amortization and so on. These expenditures are called accounting expenditures. Accounting profit is the difference between the gross revenue and accounting expenditures.

According to the economic theory expenditures are seen from the wasted chances opportunity cost. When choosing some variant, any manager thereby refuses other variants. As a result, these wasted chances of gaining the revenue in other spheres will be the opportunity costs. They are also called implicit costs. Such costs are the compensation for attracting the resources to an enterprise. [3]. Various economists consider that a manager's competence is revealed when making such a choice. Consequently, the economic profit is the difference between the gross revenue and implicit expenditures. [4].

The tax basis is strictly regulated by the Tax Code. At the same time, the amount of profit tax is formed within the system of tax registration the basis of which is the information, generalized in the accounting registration system. Such interrelation obliges paying more attention to the profit as an accounting category, i.e. to the difference between the gross revenue and explicit expenditures.

Thus, the quantitative assessment and identification of factors, which influence an enterprise's profit, is done basing on the financial results' analysis. In general, the assessment of financial results begins with studying the profit's dynamics and structure and ends with calculating profitability coefficients. The united, common analysis methods hamper calculating and interpreting the data because of each business sphere and condition's peculiarities. This problem is topical for big businesses.

Further planning and forecasting is possible basing on the analysis of the collected information only. Nowadays Russian enterprises use standard financial analysis methods only, based on calculating various financial sustainability coefficients, solvency, profitability and financial results' dynamics for assessing the potential development opportunities. An Enterprise's Accounting (financial) statements are the main information source

The world practice of assessing the enterprises' financial state has formed numerous approaches to analyzing the financial results and making conclusions (recommendations) on how to make a decision, aimed at stabilizing and further advancing financial results. At the same time, it is possible to adapt foreign financial state analysis methods and apply them in Russia.

Each economic entity elaborates a financial results formation and registration methods system on its own, judging by the factors, which are basic for this entity. Such factors can include an entity's scale, sector, specificity and so on. We have determined that such basic factor is the strategy, oriented at an entity's internal potential and assessing the external environment's challenges (based on the works of I. Ansoff, A. Chandler, K. Andrew, B. and R. Richardson, H. Mintzberg, R. Miles, S. Snow, M. Porter and etc.). In this context strategic planning is aimed at achieving additional competitive advantages in the long-term perspective.

\section{RESULTS AND DISCUSSION}

\section{A. Determining challenges and threats to Volgograd Oblast's economic security}

Basing on Volgograd Oblast's socio-economic development regional policy's analysis, the main threats are the "increasing structural imbalances" in the regional economy. Volgograd Oblast is considered to be not only an agricultural region but an industrial region as well. However, Volgograd Oblast's industry, which used to be the main sector 
in the USSR times, has faced serious changes over the last 30 years. Most enterprises have been closed down, but a few of them still function, though their production capacity and technologies became outdated. The region's large businesses face stagnation. In November, 2017, Volgograd Oblast Governor, A. Bocharov had a big meeting with deputies, political parties, public organizations' leaders and entrepreneurs. During the meeting, A. Bocharov formulated the plans on developing the region's economic sphere. Particularly, he pointed out that it was necessary to raise Volgograd Oblast's GRP up to 1 trillion rubles. It is essential to launch 23 new production enterprises until 2018 and 13 enterprises more until 2021 in order to achieve 1 trillion rubles GRP goal.

One of the top-priority goals of the economic security Strategy is to provide sustainable economic growth. In order to achieve this goal, we have formulated directions and tasks, which have to be accomplished on the regional level. There are 2 directions and corresponding tasks, represented in Figure 1 , that are the most interesting in this research's context.

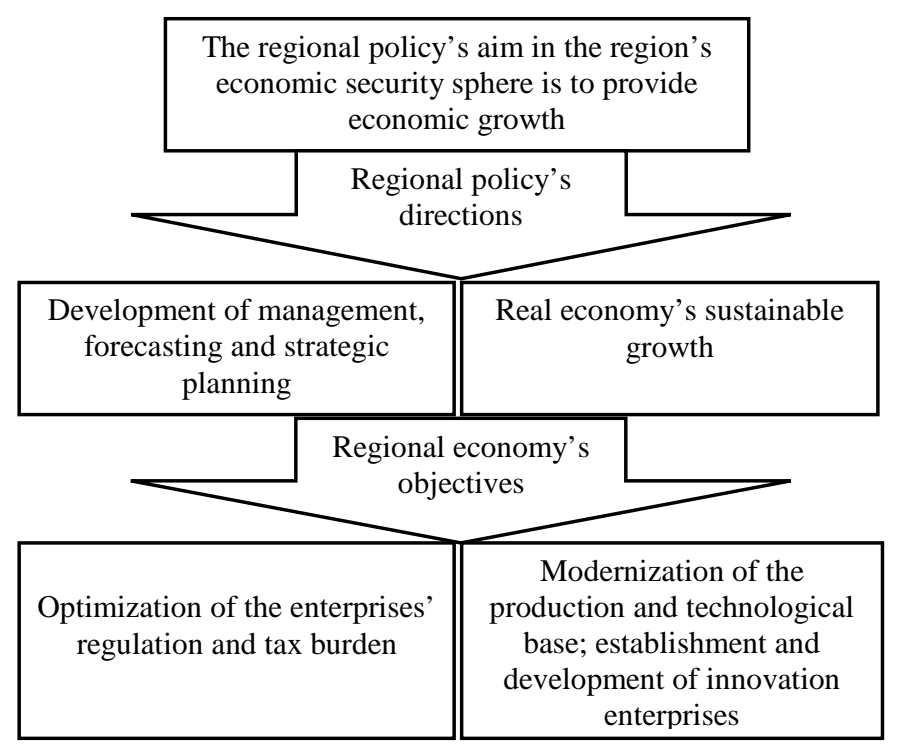

Fig. 1. Regional policy's directions and objectives for ensurring the region's eonomic growth

« As of $1^{\text {st }}$ January 2017, 51,2 thousand enterprises and 60,6 thousand individual entrepreneurs are registered in the Volgograd Oblast Economic Entities Statistical Register. Comparing with the beginning of 2013, the overall number of enterprises has decreased by 1979 economic entities (by $3,7 \%$ )»[5]. Such a tendency has been continuing for the last 5 years. Volgograd Oblast needs developing the business more than ever. Newly established enterprises will ensure not only the GRP growth but they will help create additional workplaces, solve socio-demographic problems and boost the state budget revenue.

It has been proven that the reduction of Volgograd Oblast's enterprises is partly dependent on the tax burden. "The negative impact of decreasing the enterprises' profit tax, further paid to the Russian Federation regions' budgets, from $18 \%$ to $17 \%$ has been stated. In Volgograd Oblast such a decline has happened due to the decrease in the tax payment from big businesses, which import and export goods" [6],[7]. Thus, it is essential to pay special attention to forecasting and making a strategic plan of the financial result and the profit tax on the individual enterprises' level, in order to provide the region's economic security and growth [8].

\section{B. An enterporise's profit: factors and ways to raising it}

Multiple factors affect the final financial result (Figure 2). Taking into account these factors and the ability to manage them will help optimize the final financial result. The main factors are - increasing the sales volume and decreasing the prime cost. The whole range of such factors are represented in the works of numerous economists: M. Altukhova, A. Bobovich, I. Lipsits, N. Selezneva, N. Tryastsina, A. Sheremet.

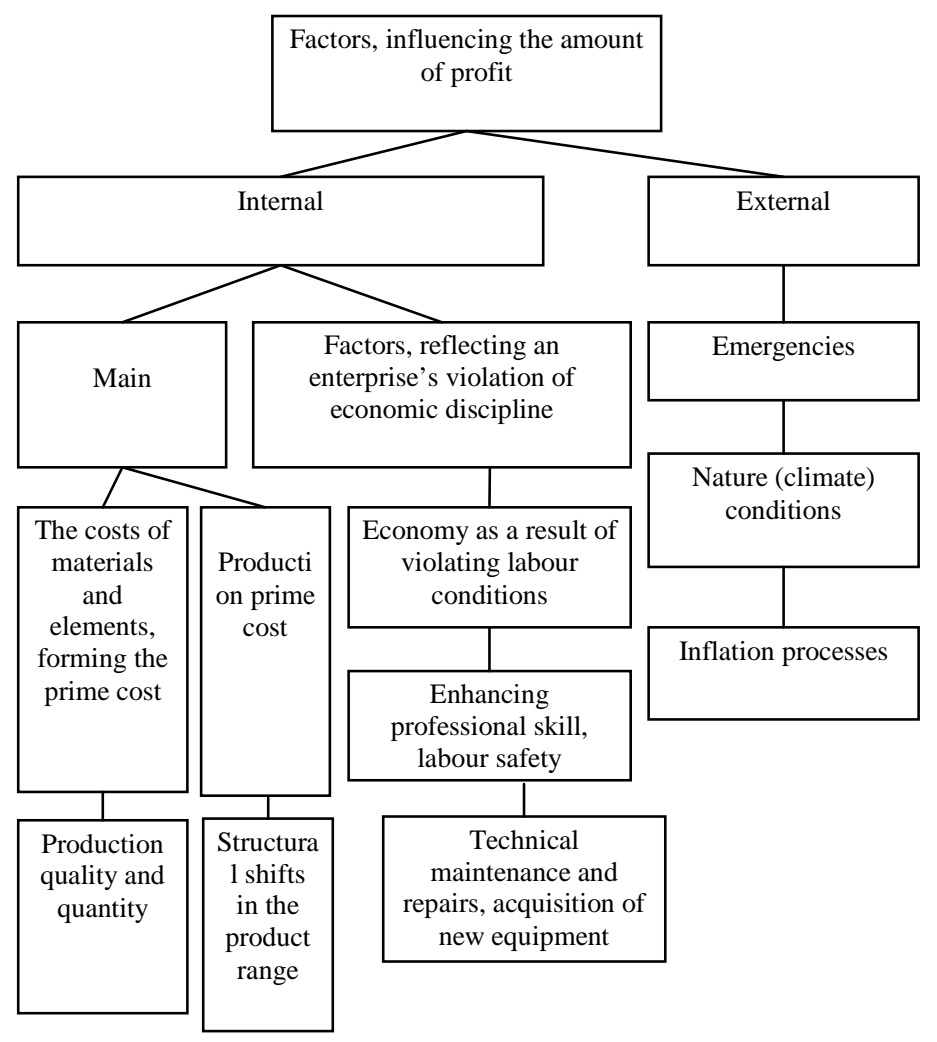

Fig. 2. Identification of factors, influencing the amount of profit, depending on an enterprise's environment

At the same time, some scholars focus on only one factor, asserting that only this particular factor is important, while others say that a whole group of factors is important. The most important factors in raising the profitability is modernization of the main assets, innovation technologies use; enhancing the production quality, improvement of labour productivity, management processes automation, introduction of the innovative sales methods, raising the prices and etc.. [9]

There is one more specific internal factor, such as accounting methods system, fixed in an enterprise's accounting policy (Table 1) [10]. 
TABLE I. WAYS OF KEEPING ACCOUNTING RECORDS AND THEIR ELEMENTS, AFFECTING THE FINANCIAL RESULTS' SCALE

\begin{tabular}{|c|c|}
\hline Ways & Elements \\
\hline $\begin{array}{l}\text { 1. Ways of } \\
\text { calculating the main } \\
\text { assets'depreciation } \\
\text { accrual }\end{array}$ & $\begin{array}{l}\text { 1.1. Straight-line } \\
\text { 1.2. Declining balance method } \\
\text { 1.3. Cost depriciation with respect to the } \\
\text { total number of years use } \\
\text { 1.4. Cost depriciation in proportion to the } \\
\text { production volume }\end{array}$ \\
\hline $\begin{array}{l}\text { 2. Ways of } \\
\text { calculating the } \\
\text { intagible } \\
\text { assets'depreciation } \\
\text { accrual }\end{array}$ & $\begin{array}{l}\text { 2.1. Straight-line } \\
\text { 2.2. Cost depriciation in proportion to the } \\
\text { production volume (works, service } \\
\text { volume) } \\
\text { 2.3. Declining balance method }\end{array}$ \\
\hline $\begin{array}{l}\text { 3. Ways of assessing } \\
\text { material resources, } \\
\text { included in the } \\
\text { production expenses }\end{array}$ & $\begin{array}{l}\text { 3.1 By an item's prime cost } \\
\text { 3.2. By the average prime cost } \\
\text { 3.3. By the prime cost of the first } \\
\text { acquisitions (FIFO) }\end{array}$ \\
\hline $\begin{array}{l}4 \text { Distribution of } \\
\text { expenses by their cost } \\
\text { outlay time }\end{array}$ & $\begin{array}{l}41 \text {. To the production expenses financial } \\
\text { accounts } \\
4.2 \text {. To the «Prepaid expenses» } 97 \\
\text { account } \\
\text { 4.3. To the «eserves for future expenses» } \\
96 \text { account }\end{array}$ \\
\hline $\begin{array}{l}\text { 5. Creation of } \\
\text { account reserves by } \\
\text { charging to the } \\
\text { financial results }\end{array}$ & $\begin{array}{l}\text { 5.1. To the «Reserves for the material } \\
\text { assets' cost depriciation» } 14 \text { account } \\
\text { 5.2. To the «Securities investment } \\
\text { impairment reserves» } 59 \text { account } \\
\text { 5.3. To the «Bad debts reserves» } 63 \\
\text { account } \\
5.4 \text {. Не производится }\end{array}$ \\
\hline $\begin{array}{l}\text { 6. Ways of grouping } \\
\text { production expenses }\end{array}$ & $\begin{array}{l}\text { 6.1. Way of forming full prime cost } \\
6.2 \text {. Way of forming the prime cost } \\
\text { «direct-costing» principles }\end{array}$ \\
\hline
\end{tabular}

Internal factors, affecting the financial result, are subdivided into two groups: extensive and intensive. They are generally associated with studying economic growth. This research authors suggest considering the extensive and intensive factors system for determining their influence the amount of profit. Extensive factors affect the amount of profit by means of quantitative changes and the main directions of increasing the profit are considered to be the sales volume growth and the prime cost reduction. Intensive factors influence the amount of profit through qualitative changes. Typical examples of intensive factors include equipment modernization, the search for new raw material sources, reduction of labour intensity through automation, application of new technologies and so on. The above-mentioned factors are primarily the top managers' prerogative. However, an enterprise's financial service can make its contribution to developing the business as well.

\section{Modelling an enterprise's financial results assessment system}

A whole set of financial result analysis methods are used in Russia. We can distinguish 3 groups of methods according to their essence. Here we would like to rely on the works of G. Savitskaya, A. Sheremet, A. Ionova, N. Selezneva.
We suggest using the below-mentioned matrix for choosing this or that model (Table 2). This matrix presents the advantages and disadvantages of models suggested. An enterprise chooses the most priority factors and chooses a model, which meets the strategic planning demands.

TABLE II. MATRIX OF CHOOSING A FINANCIAL RESULTS ANALYSIS MODEL

\begin{tabular}{|c|c|c|c|c|}
\hline \multirow[b]{2}{*}{$\begin{array}{l}\text { Stakeholder' } \\
\text { s } \\
\text { requirement }\end{array}$} & \multirow[b]{2}{*}{ Economic effect } & \multicolumn{3}{|c|}{$\begin{array}{c}\text { Financial result } \\
\text { analysis models by }\end{array}$} \\
\hline & & 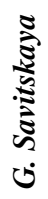 & 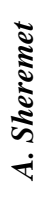 & 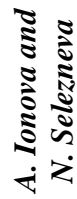 \\
\hline $\begin{array}{l}\text { Optimization } \\
\text { of pricing } \\
\text { policy }\end{array}$ & $\begin{array}{c}\text { Maintaining production's } \\
\text { competitiveness with a } \\
\text { projected profit level }\end{array}$ & + & - & - \\
\hline $\begin{array}{l}\text { Assessment of } \\
\text { the inflation } \\
\text { influence }\end{array}$ & $\begin{array}{l}\text { Forming a real view on } \\
\text { financial results taking } \\
\text { into accounts assets' } \\
\text { depriciation }\end{array}$ & - & + & + \\
\hline $\begin{array}{c}\text { Plan } \\
\text { fulfilment }\end{array}$ & $\begin{array}{l}\text { Allows assessing an } \\
\text { enterprise's potential }\end{array}$ & + & - & - \\
\hline $\begin{array}{l}\text { Profitability } \\
\text { growth }\end{array}$ & $\begin{array}{c}\text { Allows assessing } \\
\text { efficiency }\end{array}$ & + & + & + \\
\hline $\begin{array}{l}\text { Marginal } \\
\text { analysis }\end{array}$ & $\begin{array}{l}\text { Allows forming the most } \\
\text { profitable combinations of } \\
\text { price, variable and fixed } \\
\text { costs }\end{array}$ & + & + & - \\
\hline $\begin{array}{l}\text { Horizontal } \\
\text { and vertical } \\
\text { analysis }\end{array}$ & $\begin{array}{c}\text { Analysing the indicators' } \\
\text { dynamics }\end{array}$ & + & + & + \\
\hline $\begin{array}{l}\text { Competitors' } \\
\text { behaviour } \\
\text { assessment }\end{array}$ & $\begin{array}{l}\text { Determining competitors' } \\
\text { strengths and weaknesses, } \\
\text { forecasting their future } \\
\text { actions }\end{array}$ & + & - & - \\
\hline $\begin{array}{l}\text { Factor } \\
\text { analysis }\end{array}$ & $\begin{array}{l}\text { Studying each factor's } \\
\text { influence on the resulting } \\
\text { indicator }\end{array}$ & + & + & + \\
\hline $\begin{array}{l}\text { Other income } \\
\text { and expenses } \\
\text { analysis }\end{array}$ & $\begin{array}{l}\text { Manging the pre-tax } \\
\text { profit }\end{array}$ & + & - & + \\
\hline $\begin{array}{l}\text { Income } \\
\text { analysis of } \\
\text { each activity }\end{array}$ & $\begin{array}{l}\text { Defining the most } \\
\text { perspective activity } \\
\text { direction }\end{array}$ & - & - & + \\
\hline $\begin{array}{l}\text { Focus on } \\
\text { small } \\
\text { businesses } \\
\text { (application } \\
\text { simplicity) }\end{array}$ & $\begin{array}{l}\text { Time saving while } \\
\text { calculating, simple results } \\
\text { interpreting }\end{array}$ & + & + & - \\
\hline $\begin{array}{l}\text { Profit use } \\
\text { analysis }\end{array}$ & $\begin{array}{l}\text { Searching for an optimal } \\
\text { combination of ways to } \\
\text { use profit }\end{array}$ & + & - & - \\
\hline $\begin{array}{l}\text { Tax burden } \\
\text { analysis }\end{array}$ & $\begin{array}{l}\text { Aims at optimizing the } \\
\text { tax base }\end{array}$ & + & - & - \\
\hline
\end{tabular}


We would like to point out the significance of each factor.

The pricing policy is normally aimed at raising the sales' profitability. Gaining and keeping the sales target audience is possible by decreasing the profit margin with the help of the growing sales volume. Such a problem can be solved in the framework of financial results analysis.

Inflation distorts the financial results view. Consequently, it is necessary to correct monetary indicators for assessing their depreciation rate.

Assessment of plan fulfilment according to the indicators set allows determining an enterprise's potential. In case a plan is not fulfilled it is necessary to find out the reasons of it and develop measures on preventing such a problem in future.

Profitability - is an economic efficiency relative indicator, which reflects the material, labour, monetary and other resources' effective use.

Marginal analysis helps derive the most profitable combinations of variable expenses per production item, fixed expenses, price and sales volume. Its main goal is to calculate the sales volume necessary for the amount of profit set. It implies finding the break-even point and financial security zone and is the main part of analysis.

The aim of the horizontal and vertical analysis is to represent the changes, which happened in the main parts of the financial results report and to help an enterprise's managers make a decision on how to continue further business.

The calculated indicators are better to be compared with the recommended ones in this sector and with the competitors' indicators. The competitors' pricing and marketing policy analysis will help finding the enterprise's strengths and weaknesses.

Factor analysis is aimed at investigating each factor's influence on the resulting indicator. Along with the marginal analysis, factor analysis is an integral part of the financial result analysis method.

In case, other incomes and expenses are high, it is essential to control their dynamics, what will help determine unnecessarily high other expenses types and reserves of increasing other incomes. Each type of other incomes and expenses follow certain reasons.

Income analysis of each activity will allow finding out the most perspective development directions. Such information may be useful for making further management decisions.

Overcomplicated methods will be useless for small and medium businesses. They need a brief and precise algorithm with a simple interpretation of final indicators.

Profit use analysis is based on comparing its real distribution over the reporting period with the planned distribution in its dynamics.

Tax burden analysis is one of an enterprise's top priority objectives. The measures on decreasing the tax base will depend on the enterprise's taxation system. Consequently, the tax burden analysis will allow assessing these measures effectiveness.

\section{CONCLUSION}

\section{A. Determining Volgograd Oblasts economic security challnges and threatschallenges and threats}

Having analyzed Russia's economic security Strategy until 2030 and the current economic situation, we have determined the key challenges and threats to the region's economic security, which include the decreasing number of enterprises, growing labour force outflow, small and medium business's small share in the GRP.

In order to minimize these challenges and threats, we have formulated the priority directions and regional policy's tasks for ensuring the region's economic growth.

Decreasing the profit tax to the $17 \% \mathrm{~m}$ lowering the number of enterprises'-taxpayers and negative financialeconomic activity indicators of many economic entities determine the decline of the state budget revenue. Therefore, there is a huge necessity for making forecasts and financial results plans on an individual enterprise level by implementing a set of procedures and strategic planning.

\section{B. An enterprise's profit: factors and ways to increase it}

After having analyzed the term "profit" from the economic and accounting points of view, we have concluded that it really is a multi-form phenomenon. In this research we have paid special attention to the accounting point of view on the term "profit". We have systematized the ways of keeping its record and its elements, which affect the amount of the financial results.

We have identified the factors, influencing the profit amount, depending on the enterprise's environment, based on distributing the internal factors into extensive and intensive and defining the prices dynamics on the raw materials market, people's purchasing power and infrastructure's development as external factors. Finally, we have justified the necessity to specify additional internal factors: an enterprise's management strategy and financial results analysis methods.

\section{Modelling the enterprises' financial results assessment system}

We have assessed and identified the advantages and disadvantages of analysis methods of the following Russian economists G. Savitskaya, A. Sheremet, A. Ionova, N. Selezneva. We have elaborated the choice matrix of the financial results analysis model, which is based on the compilation of the well-known methods. The distinctive feature of this model is the variability of financial analysis instruments, depending on the stakeholders' requirements, which is aimed at mo=inimizing the challenges and possible negative results. 


\section{References}

[1] Russian Federation President's Decree as of 13.05.2017 N 208 "On the Russian Federation's Economic Security Strategy until 2030"

[2] Volgograd Oblast's Law as of 21.11.2008 N 1778-OD "On Volgograd Oblast's Socio-Economic Development Strategy until 2025"

[3] A. Gukova "Technology of increasing the financial result of enterprises: theory and practice", textbook- Volgograd 2013, P. 44

[4] A. Popov "Economic Theory" / A. Popov. - SPb.:Saint-Petersburg, 2006. - P. 139

[5] Volgograd Oblast in Figures. 2016 : brief collection / Territorial Body of the Federal State Statistics Service in Volgograd Oblast - Volgograd : Volgograstat, 2017. - P. 136

[6] Volgograd Oblast Administration’s Letter as of 14.07.2017 № 04$13 \mathrm{~m} / 9652$
[7] Short-Term Information on the Implementation of Consolidated budgets of the Russian Federation Regions over January-May 2017

[8] A.V. Glushchenco, Y.P. Kucherova, I.V. Yarkova "Ensuring an agricultural holding's economicsecurity by means of sustainable development strategies in terms of globalcrisis management". Revista Espacios, № 39 (9), 2018

[9] N. Tryastsina, N. Tryastsin "Financial results factor analysis as an organization management instrument”. Moscow Economic Journal, №3, $2016-$ P.18

[10] L. Sotnikova, "Accounting records of an organization". - M.: Russia's Professional Accountants Institute: Information Agency «ИПЬБИНФА», $2005-54$ p. 